\title{
A Study on Carbon Financing Innovation of Financial Institutions in China
}

\author{
Yuanyuan $\mathrm{Ma}^{1}$ \\ ${ }^{1}$ School of Finance \& Economics, Shandong Jiaotong University, Jinan, China \\ Correspondence: Yuanyuan Ma, 202, Unit 4, Building 4, Qilu Garden, Dikou Road, Tianqiao District, Jinan, \\ Shandong, China. Tel: 86-138-5314-6989. E-mail: myy_09@163.com
}

Received: July 10, 2014

doi:10.5430/ijba.v5n4p103
Accepted: July 16, 2014

Online Published: July 19, 2014

URL: http://dx.doi.org/10.5430/ijba.v5n4p103

This paper is sponsored by Humanities and social sciences research project of Shandong Provincial Department of Education through "Risk Management of Dynamic Asset Allocation in Insurance Company"(Award Number J11WG16) and the project of "The research on improving cultural "soft power" of the financial industry in Shandong province based on internet finance " from Shandong Provincial Department of culture. The full text of this report may be reused under the condition of an acknowledgement and a correct reference to this publication.

\begin{abstract}
In the past few years, commercial banks and other financial institutions have devoted to the development of financial products and financial services innovation, which becomes a new bright spot in the development of international financial market. It provides a huge space for developing carbon finance system. Chinese low-carbon economy has made considerable progress, but the development remains at a relatively early stage. This paper presents several bottlenecks of involvement in carbon finance of Chinese financial institutions, the establishment of a carbon credit trading platform, strengthening the impact of financial institutions as fund agent and trading agent and promoting the innovation of carbon financial products.
\end{abstract}

Keywords: carbon finance, carbon trading, financial institutions, financial innovation

\section{Introduction}

People around the world have paid more attention on low-carbon economy since 2008, which made the space of Chinese financial institutions increasingly apply to participate in carbon finance. As a branch of environmental finance, carbon finance is about financial activities related to carbon trading, such as direct investment, carbon index trading and bank loans, etc. That is another type of financial operation model to regulate the carbon emissions.

With a short history, carbon finance is considered to be important financial innovation of international finance in recent years. Global carbon finance market is showing a trend of rapid development. Barclays Bank launched the first standardized OTC (Over the Counter) CER (certified emission reduction) futures contract since October 2006, and the Netherlands Bank and the German Dresden Bank developed and tracked the retail products of EU carbon emission quotas futures by 2008. At the same time, investment banks began to participate in the carbon finance market in a more direct way, which involved in Clean Development Mechanism (CDM) of emission reduction projects. Later on, Kanji Bank in Korea, as an emerging market institution, has also introduced a "Carbon Bank "program.

It's extremely rich in carbon emissions resources, and with a great potential in carbon emission reduction in China. According to UNDP (United Nations Development Program) statistics, it shows that Chinese carbon emission reduction is to the level of $1 / 3$ among the global market ranking the second. It indicates that a great demand and profitability of financial opportunities, and carbon finance market has a sustainable development.

Developing low carbon and constructing the ecological culture have become an irreversible trend. "A low-carbon economy" is becoming the strategic choice to realize sustainable development around the world. However, as an essential part of the carbon market, the financial institutions in China are now barely involved in the market, offering only simple services, though with great potential of innovations and profits. Carbon finance which promotes low-carbon economic development is different from the traditional financial innovation and financial activities. The 
carbon demand for financial services gives birth to a low carbon economy, and brings modern financial industry to expand further areas and space. The development of China's carbon finance exists a series of constraints and how to break through these barriers is a topic that should be solved.

\section{The Necessity of Developing Carbon Finance Business Innovation of the Financial Institutions}

It has great significance of developing carbon financial system in the developed countries. This is particularly true for the developing ones. On one hand, it is very important to the economic transition. It contributes to the transition of domestic real economy into the low-carbon type, and can also speed up the adjustment of economic structure. On the other hand, for the financial industry, the great perspective of low-carbon economy also means the arrival of historical opportunities. As a carrier of financial system innovation, carbon financing is to the benefit for optimizing the financial system structure in China, improving the cooperation of financial institutions between China and other countries.

With the booming carbon-trading market, China's commercial banks and other financial institutions also have a positive attempt to this new financial model. There have been considerable innovations in the monetary field. In 2007, China launched the first Chinese Green Carbon Fund. Later on, the Carbon Fund started expanding continuously in Beijing, Shanxi, Dalian, Wenzhou and other places. Commercial banks have also carried out on carbon finance businesses, launching $\mathrm{CDM}$ project financing and designed products linked to carbon trading and other services and products, such as green credit business innovation of CIB (China Industrial Bank).

Despite Chinese low-carbon economy related financial innovation has made considerable progress, however, the development is still at a relatively early stage. Because of simple type of business, there are many aspects needed to be improved. Thereby, it is particularly important to research relative products, system innovation of commercial banks and other financial institutions in the carbon finance.

Raised in the 20th century and the mid-1990's scrutiny of financial institutions "function point" by Ziv Bodie and Robert Morton (Robert Mer-ton), corresponding to the carbon finance market in China, the requirement of the theory will be refined to keep the situation and prospect of the market. Undoubtedly, it promotes the financial market and improves the resource allocation efficiency of carbon finance. Commercial banks, for example, CDM project contains on the huge demand for financial intermediation services, can expand the intermediary business revenues and optimize the income structure by providing the provision of related financial services. As a contemporary business, carbon finance needs commercial banks to innovate business mode of operation which can promote the innovation capacity of commercial banks objectively. Moreover, CDM often involves in cooperation between financial institutions from two or more countries. Commercial banks can take to improve international business negotiation skills, strengthen the business relationship between the international financial institutions and accumulate experiences in transnational operations.

In addition, the rise of carbon trading and new energy sources is becoming a huge market for a wide range of excellent opportunity to boost the currency diversification. Building the carbon financial system will be helpful to contribute to get hold of more chips in the internationalization of RMB in China.

\section{Problems on Financial Institutions Participating in Carbon Financing Innovation}

The construction of the carbon finance market in China is far behind from the developed countries. In reality, China is now establishing a national carbon finance market. Chinese financial institutions, represented by commercial banks, may face various problems and obstacles. It is necessary in detailed proposals on those situations in the light of products and institutional innovation that may participate in carbon finance in China. Not only the significance and possible exploration of the preliminary theory on carbon finance market can be established in China, but also it is the complement and expansion of financial innovation of financial institutions.

\subsection{The Development of China's Carbon Trading Market Is in Its Early Stage Which Lacks of a Domestic Carbon} Exchange

At present, China is still at the initial stage of carbon trading market lack of national carbon exchanges. The developed countries dominate global carbon exchanges. Up to date, there are 7 carbon exchanges. For instance, Beijing Environment Exchange (established in 2008), Shanghai Environment and Energy Exchange and the Tianjin Emissions Exchange are the earliest of the three environmental rights trading institutions. Shanxi Lvliang Emission Reduction Trading Centre, Wuhan, Hangzhou, Kunming and other exchanges that have been established since 2009. The carbon trading system has its characteristic gradually. However, Chinese carbon trading is mainly for the European to develop some of the rules for buying or sell. The real Chinese carbon trading market has not yet appeared, and the carbon exchanges across the country have not been established. 


\subsection{The Current Market Development of the Relevant Intermediary Is Not Complete}

Carbon emission is a virtual commodity under the CDM. The trading rule is very stringent with a more complex development process. The contract period is so long that no professional organizations have the capability to develop and implement. Assessment of CDM projects abroad and the purchase of most of the emissions are done by the intermediaries, and local agencies in China are still in its infancy. It's difficult to develop or to digest a large number of projects. In addition, we're currently lacking of professional technical advisory system to help financial institutions to analyze, evaluate, and avoid project risk and transaction risk.

\subsection{Financial Institutions Are Not Mature}

It is imperfect on the carbon finance mode of operation. The quota of carbon reducing effluence under CDM is a type of virtual goods. The trading rules are very strict, and development program is more complex. At the same time, the contract period is a long time. As a consequence of the above, non-professional institutions is therefore difficult to have such a project development and execution ability.

The assessments and permits to buy of the CDM projects are completed by intermediaries mostly in foreign countries. In contrast, local agencies in China are still in the beginning stage, who are difficult to develop or absorb a lot of projects. In addition, at present China is the lack of professional technical consulting system to help financial institutions analysis, evaluate and avoid project risk.

Finally, it is not yet mature for commercial banks in China to operate carbon finance, develop projects and formulate the rule of carbon finance. A series of risks and difficulties become hinder the pace of innovation of the carbon financial business. Only a handful of commercial banks, such as China Industrial Bank, focus on carbon finance business.

\section{Analysis of Carbon Finance Development Path of Financial Institutions}

The financial markets have made a rapid and strong reaction with the continuously strengthening to cope with climate change policy. Firstly, mainstream international commercial banks assess related environmental impact actively when they step up their loan business. At this point, it is critical to monitor ecological risks strictly when issuing loans. In the meantime, commercial banks increase loans of low carbon consumption actively.

Secondly, all kinds of financial innovation associated with climate change emerge as the times require. Arbitrage products are developed continuously which connect different markets, such as the swaps between CERs (certified emission reductions) and ERUs, options based on the spread of CERs and EUAs. These financial products can not only can lock, isolation and evade the risks associated with climate change, which make people more stable expectations for the future. Beyond this, innovative products also can improve the efficiency of the price mechanism to make the allocation of resources in the cleaner production technical departments. What is more, through transparent pricing in financial markets carbon indexes, the carbon financial system, which includes direct investment, bank loans, carbon funds, index of carbon trading and carbon options, futures and other financial instruments, can be optimized.

\subsection{Constructing Carbon Credit Trading Platform}

We are required to explore carbon emissions quota further and develop the trading market of emissions quota. To create a stable environment for the development of carbon finance it is urgent to establish and improve standards of risk assessment of carbon and strengthen the price fixing right for carbon credit trading in the international market. The progress of Chinese carbon trading platform should be based on the policy and targeted at economic effect to build a multi-level system includes spot trading and derivatives trading. As the market is still in the initial rearing period, inactive trading hinders the platform in action. A more clear policy direction is needed to encourage Chinese enterprises to enter the market for trading during the "12th Five-Year Plan" period. For in that way alone can we encourage the development of spot trading platform, encourage futures and other derivatives trading platform to join.

\subsection{Play the Full Role of the Non-Governmental Organization and Financial Institutions}

We need to pay attention to the role of financial institutions as financial intermediaries and trading intermediary. The financial intermediaries are allowed to purchase or improve the project by themselves or united with the owners of carbon reduction project. Commercial banks should explore more modes. Especially the intermediary service models to satisfy carbon credits to meet the diversity of financing are needed except for the carbon rights that have been carried out secured loans and related financial products. Investment banks and financial companies should explore carbon finance products providing new investment ways for investors. Accounting firms and asset appraisal agencies need to improve the assessment and advisory work of financial products. In addition, insurance companies and other 
security companies may provide some related insurance products and promote carbon financial product development and transact by strengthening guarantee systems of trust.

\subsection{Efforts to Promote Carbon Finance Product Innovation}

\subsubsection{Promoting commercial banks to Innovate in Financial Business}

The pledge loan based on carbon emission has been promoted in China. As a kind of financing ways, pledge loan based on carbon emission is good potential for CDM (Clean Development Mechanism) project development and corporation credit because of a pledge to CERs income right to apply for loans for banks, which is of an innovative form of innovation. CERs income right is a right to future earnings, and it has a great uncertainty. Hence, commercial banks are required to pay more attention to the risk of achievements of the right CERs income when providing pledge loans for enterprises. As for enterprises that acquired CERs must go through CDM projects approved by the enterprise. The authenticity and validity of CERs issued are paid more attention, too. CDM projects registered in the $\mathrm{UN}$ need to be closely tracked the progress of the project, and up-float interest rate appropriately in case of risks.

\subsubsection{Developing Financial Leasing Business Based on Carbon Trading}

Enterprises are not necessary to purchase pollution discharge or dirty oil treatment facility owing to Clean Development Mechanism (CDM) project, which releases the circulating capital of the company. In practice, in order to encourage companies to reduce carbon emissions, financial leasing can be combined with carbon right pledge loan. It offers loan support for the companies that use leased equipment, but also can reduce the risk of CERs right benefits and decrease the possibilities of bad debts of carbon credit secured loans. Of course, finance leasing might also be combined with the factoring business.

\subsubsection{Develop Financial Products of Carbon Fund Actively}

The most influential low carbon indexes include the standard \& Poor's 500Carbon efficiency index, the European low carbon 100 and the S\&P/IFC carbon efficiency index. China's first low carbon index is announced in June 2010, issued by the Beijing Environmental Exchange and the fund of Clean Technology Investment. In the same year, the South Newspaper launched the south low carbon 50 index in Shenzhen Stock Exchange, which is the first low carbon index listed on the stock exchange.

Commercial banks, securities companies and fund companies and other financial institutions can actively explore the carbon fund market. They can not only develop and design investment and management plan to specially targeted customer, but also they can sell the open-ended fund management plan for general public investors based on the analysis of potential target customers. Idle funds gathering from the customers form a dedicated carbon fund to apply to the enterprises with a clean development mechanism (CMD) projects of development potential and credit records. CDM projects get fund smoothly. At the same time, customers can benefit from the profits of carbon emissions index sold by the enterprises. In general, the CDM project development cycle takes a long time. The approval process is more complicated and risky. Therefore, this kind of product is longer than the other, generally should be designed for $2 \sim 3$ years. The expected returns should be $20 \% \sim 30 \%$ higher than that of deposit rates over the same period.

\subsubsection{Develop Trust Products of Carbon Finance}

Such design philosophy is for those with environmental awareness and knowledge of the enterprises to set up carbon finance investment fund. The capital will be invested in development potential project of clean development mechanism (CDM) to obtain the corresponding CERs (CDM emission reduction units) indexes through the progress of these projects. Commercial banks or other financial institutions can operate these carbon trust of financial products.

\subsubsection{Gradually Promoting the Asset Securitization of Carbon Finance}

The asset securitization of carbon finance means that the companies will sell the Clean Development Mechanism (CDM) projects which have significant potential to a special purpose agency or company (SPV) (usually are investment banks). SPVs will import these carbon assets to the asset pool. The securities are issued to finance backed by the cash flows coming from asset pool. The cash flow will pay back all of the issued securities, too. The assets portfolio supported by the pledge loans of commercial banks, financing lease, account receivable of carbon emission and bank factoring portfolio formed an asset pool, which issues portfolio to ensure the value of relevant assets. The securitization of carbon assets improves liquidity of the carbon asset, and the risk is transferred. It's conducive to the progress of carbon finance. In order to encourage investment banks to promote securitization of carbon asset, the risk assessment institutions must be strengthened to evaluate carbon capital. At last, it is necessary to establish the credit mechanism of carbon asset-backed securities. 
In addition, carbon finance is surely a huge market for financial institutions. However, there are also hidden financial risks that traditional products don't have. Carbon insurance is still vacant in China, and it is also pressing for exploration.

\section{Conclusion}

How to develop "carbon finance" is a system which is required to set specific standards. In accordance with the principles of sustainable development, government, regulators and financial institutions must build a mature carbon trading system, as well as scientific and rational interest compensation mechanism to improve the carbon finance markets and carbon financial instruments. Financial institutions will play more and more role in investment and financing activities of energy saving and economic sustainable development.

\section{References}

Jie W., \& Ruxiao Q. (2010). The contermeasures of improving cabon credit mechnism in China. Asian-Pacific economy.

Lijun S. (2010). International carbon credit market development and innovation of carbon financial products. Economic Review, 6, 30-35.

Nicholas Stem. (2006). Review on the economics of climate change. Cambridge University Press, Cambridge, UK.

Qian W, etc. (2010). Analysis of development of China's carbon finance strategy and path. Social Science Journal, 3, 147-149.

Qiuling Z., \& Yiyi S. (2010). How to construct the system of carbon finance in China duing era of low-carbon economy. New Finance.

Ruihong L. (2010). Some Reflections on Carbon Finance in China. Economy of Tianjin, 5, 86-89.

Sonia Labatt, \& Rodeny R. White. (2002). Environmental Finance. New York: John Wiley and Sons.

Stern, N. (2007). The Economics of Climate Change: The Stern Review. Cambridge, UK: Cambridge University Press.

Yeqiong W. (2010). Carbon Finance- New opportunities of development of financing. Financing of Zhejiang, 7, 36-39.

Retrieved from http://finance.Caijing.Com.cn/2012-05-14/111846964.html 